\title{
PERBAIKAN REPRODUKSI KAMBING PERAH DI KTT AS-SALAM MELALUI PENGEMBANGAN UREA MOLASES BLOK (UMB)
}

\section{IMPROVEMENT OF DAIRY GOATS REPRODUCTION IN KTT AS-SALAM THROUGH THE DEVELOPMENT OF UREA MOLASES BLOCK (UMB)}

\author{
${ }^{1)}$ Dwi Wijayanti, ${ }^{2}$ Firgian Ardigurnita \\ 1,2,)Program Studi Peternakan, Fakultas Pertanian \\ Universitas Perjuangan Tasikmalaya \\ Jl. Peta No. 177, Kahuripan, Tawang, Tasikmalaya, Jawa Barat, Indonesia. \\ *Email: wijayantidwi12@gmail.com, firgianardigurnita@unper.ac.id
}

\begin{abstract}
ABSTRAK
Kambing perah di daerah Sinargalih yaitu Kelompok Ternak (KTT) AS-Salam memiliki produksi susu di Kelurahan Sirnagalih mengalami penurunan karena kekurangan kalsium. Tujuan dari pengabdian ini adalah pengembangan Urea Molases Blok (UMB) untuk meningkatkan status reproduksi kambing Peranakan Etawah (PE). Mitra pengabdian dari Kelompok Ternak As-Salam. Metode pengabdian yaitu survey, transfer teknologi, dan plot demonstrasi. Hasil pengabdian yaitu pelaksanaan pengabdian masyarakat ini berhasil dengan baik dibuktikan dengan antusiasme dari mitra dan anggota kelompok ternak As-Salam dalam mengikuti kegiatan ini cukup besar. Setelah kegiatan pengabdian ini, terjadi peningkatan pemahaman dan keberhasilan pembuatan UMB dalam rangka meningkatkan performans reproduksi kambing Peranakan Etawah. Selain itu, diperoleh juga adanya peningkatan nafsu makan pada kambing Peranakan Etawah.
\end{abstract}

Kata kunci: Kambing Perah; Molasses; Urea; Pakan

\section{ABSTRACT}

Dairy goat in Sinargalih, As-Salam Goatherd Group, experienced a decline due to calcium deficiency. This service aimed to develop Urea Molasses (UMB) to improve the reproductive status of the etawah crossbreed goat. The service colleague was As-Salam Goatherd Group. The method of the service was survey, technology transfer and demonstration plot. The service results were that this community service was done successfully, proven by the huge enthusiasm of the colleagues and members of As-Salam goatherd group in following this activity. After this community service, there were improved understanding and the success of making Urea molasses Block (UMB) in improving the etawah crossbreed goat's reproduction performance. Besides, the appetite of etawah crossbreed goats was increased.

Keywords: Dairy Goat; Molasses; Urea; Feed

Submitted : 21 Februari 2020 Revision : 21 Februari 2021 Accepted : 21 Maret 2021

\section{PENDAHULUAN}

Potensi sumber daya alam yang ada di Kelurahan Sirnagalih Kecamatan Indihiang, Kabupaten Tasikmalaya yaitu berupa Kambing Perah. Terdapat banyak kelompok ternak yang berkembang di sana. Ada sekitar 12 kelompok ternak yang ada di Kelurahan Sirnagalih. Produksi susu yang dihasilkan menjadi salah satu penghasilan bagi masyarakat yang ada di Kelurahan Sirnagalih. Selain itu, sumber daya manusia di Kelurahan Sirnagalih menunjukkan bahwa kesadaran akan informasi sudah baik. Masyarakat di sana memiliki kompetensi dan keahlihan dalam memelihara ternak mereka dengan baik. Namun demikian, Kambing Perah yang ada di Kelurahan Sirnagalih 
memiliki permasalahan di bidang reproduksi yaitu nailai BCS (Body Condition Score) kecil. Hal tersebut menyebabkan gangguan reproduksi dan penurunan produksi susu.

Produksi susu di Kelurahan Sirnagalih mengalami penurunan karena kekurangan kalsium. Hal ini menyebabkan penurunan pendapatan peternak yang ada. Usaha yang sudah pernah dilakukan yaitu pada tahun pertama sudah dilakukan perbaikan manajemen kesehatan dan status reproduksi melalui pemberian larutan antibiotik dari herbal berupa daun binahong sebagai dipping. Namun ternyata kenaikan produksi susu tidak hanya dipengaruhi oleh manajemen kesehatan yang baik, akan tetapi faktor manajemen pakan yang ada. Pakan yang diberikan kurang memenuhi kebutuhan pokok dan kebutuhan untuk memproduksi susu. Di Kelurahan Sirnagalih sering mengalami kesulitan untuk memenuhi pakan khususnya hijaun segar. Peternak banyak mencari hijaun pakan sampai harus keluar desa bahkan ada yang harus membeli hijaun saat musim kemarau. Kurangnya ketersediaan pakan menyebabkan penurunan bobot badan sehingga BCS turun dan berakibat penurunan produksi susu serta terjadinya gangguan reproduksi berupa silent heat. Masalah pakan tidak tersedia saat musim kemarau bahkan saat musim penghujan juga menjadi kendala bagi peternak. Ketersedian tanaman berupa limbah molases. Molases memiliki energi yang tinggi namun kurang mineral.

Molases Blok salah satu teknologi pakan untuk meningkatkan nilai guna pakan. Molases Blok berupa pakan suplemen tambahan yang mengandung beberapa vitamin dan mineral yang dapat meningkatkan tingkat reproduksi ternak (Sucipta et al., 2016). Menurut (Murni et al., 2015), unsur mineral sangat diperlukan untuk menyusun struktur tubuh serta untuk aktifitas enzim dan hormon dalam tubuh. Delima (2008), menjelaskan bahwa bahan utama yang digunakan dalam campuran mineral blok adalah molases. Pengolahan ini memberikan nilai tambah karena memanfaatkan limbah pertanian dan menggunakan teknologi sederhana dengan energi yang relatif rendah dan menghemat biaya produksi. Diharapkan dengan penguatan pakan dapat memperbaiki kualitas berahi dan menaikkan Body Scoring Condition (BCS) sehingga tidak terjadi adanya silent heat dan kawin berulang. Selain itu, dengan pembuatan Urea Molases Blok (UMB) dapat dijadikan pakan simpanan ketika musim kemarau sehingga peternak tidak mengalami kesulitan pemenuhan pakan ketika musim kemarau. Hasil dari Urea Molases Blok (UMB) dapat dijual untuk penghasilan tambahan.

Program yang dilaksanakan yaitu memperbaiki manajemen reproduksi Kambing Perah yang mengalami gangguan reproduksi melalui perbaikan pakan (Urea Molases Blok (UMB). Kegiatan dilakukan melalui kerjasama dengan Kelompok Peternak Kambing Perah yang berlokasi di Kelurahan Sirnagalih, Kecamatan Indihiang, Kabupaten Tasikmalaya. Program ini dilaksanakan bersama yaitu melalui swadaya desa dan dengan potensi yang dimiliki Kelurahan Sirnagalih.

\section{METODE}

Kegiatan pengabdian yang dilakukan yaitu meliputi survey, transfer teknologi, dan plot demonstrasi.

a. Survey dilakukan dalam hal pemilihan hijauan dan kosentrat yang cocok pada Kambing Perah melalui proses pendampingan. Proses pemilihan pakan dan hitungan nilai gizi sesuai umur dan kebutuhan salah satu bentuk pendampingan serta evaluasi.

b. Transfer teknologi manfaat dan nilai gizi pakan untuk Kambing Perah dilakukan dengan metode pendampingan berupa pelatihan dan edukasi standar kualitas pakan di Indonesia. Evaluasi yang dilakukan yaitu nilai pengetahuan mitra bertambah mengenai nilai penting dari pakan.

c. Pengolahan pakan yang berupa pembuatan Urea Molases Blok (UMB) bersama kelompok peternak :

Pembuatan Urea Molases Block (UMB) untuk Kambing Perah dengan Total Komposisi 3.000 Gram 


\begin{abstract}
Bahan yang digunakan adalah mollases/tetes tebu, urea, bekatul, polard, tepung tapioka, semen, tepung kapur/kalsium, garam, dan mineral campuran (ultra mineral). Alat yang digunakan adalah timbangan, wadah tempat, pencampuran, pencetak (pipa paralon) 4 inc atau 5 inc, batang besi kecil/bambu sumpit, saringan/ayakan tepung, sendok pengaduk, dan plastik.
\end{abstract}

\section{Metode pembuatan:}

1. Bahan-bahan ditimbang dengan komposisi sebagai berikut:

tepung kapur $3 \%=90 \mathrm{~g}$, mollases $/$ tetes $10 \%=30 \mathrm{~g}$,

urea $5 \%=150 \mathrm{~g}$,

bekatul $30 \%=900 \mathrm{~g}$,

polard $10 \%=300 \mathrm{~g}$

tepung tapioka $10 \%=300 \mathrm{~g}$,

semen $20 \%=600 \mathrm{~g}$,

garam $2 \%=60 \mathrm{~g}$

mineral campuran $10 \%=300 \mathrm{~g}$,

Total komposisi $100 \%=3.000 \mathrm{~g}$

2. Semua bahan dicampur dan diaduk homogen

3. Kemudian dicetak dengan pencetak dan dipadatkan

4. Bahan dijemur selama 3 hari, setelah mengeras, diberi tali penggantung

\section{Aspek Kesehatan dan Reproduksi Ternak}

1. Aspek kesehatan dilakukan dengan metode yaitu penerapan proses vaksin pada ternak untuk menghindari penyakit yang dapat menurunkan produksi ternak. Proses vaksin dan pemberian obat dilakukan oleh dokter hewan dan tim pengabdian. Pendampingan dalam proses dipping yang benar dalam pasca pemerahan. Proses pasca dipping dapat diberikan antibiotik herbal dengan pemberian larutan daun binahong untuk membunuh bakteri.

2. Aspek reproduksi dilakukan dengan metode pemberian pakan mineral UMB selama 3-4 bulan dan dilakukan perbaikan kualitas estrus. Evaluasi yang perlu dilakukan yaitu pengukuran $\mathrm{PBBH}$ untuk bobot badan kambing. Perhitungan PBBH yaitu selisih bobot badan akhir dengan bobot badan awal dibagi selisih waktu penimbangan akhir dengan waktu penimbangan awal.
Pengenalan tanda-tanda berahi dilihat dari tingkah laku (teriak-teriak, gelisah dan nafsu makan menurun), jumlah lendir dan keadaan vulva (merah, hangat, bengkak). Pengecekan Body Condition Score (BCS) dengan perhitungan menurut Suwito et al (8), scoring yang dihitung mulai dari 1,05,0 dengan pertahapan kenaikan 0,5 . Kambing dengan score BCS 1,0 memiliki tubuh yang kurus dan tidak memiliki cadangan lemak, sedangkan BCS 5,0 kambing yang terlalu gemuk. BCS yang normal 2,5-4,0.

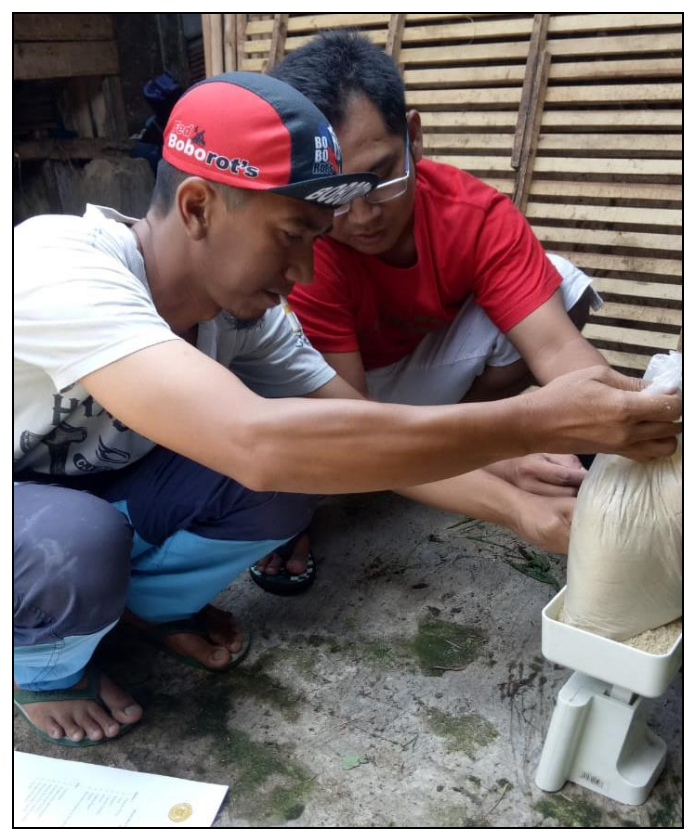

Gambar 1. Penimbangan UMB

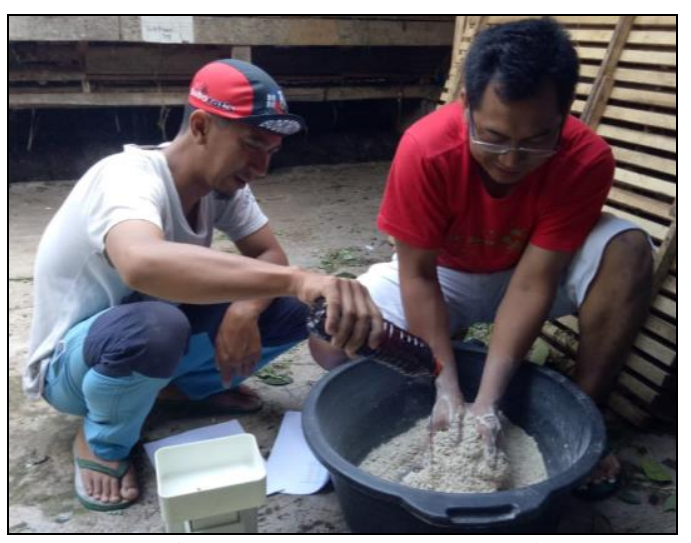

Gambar 2. Pencampuran Bahan 


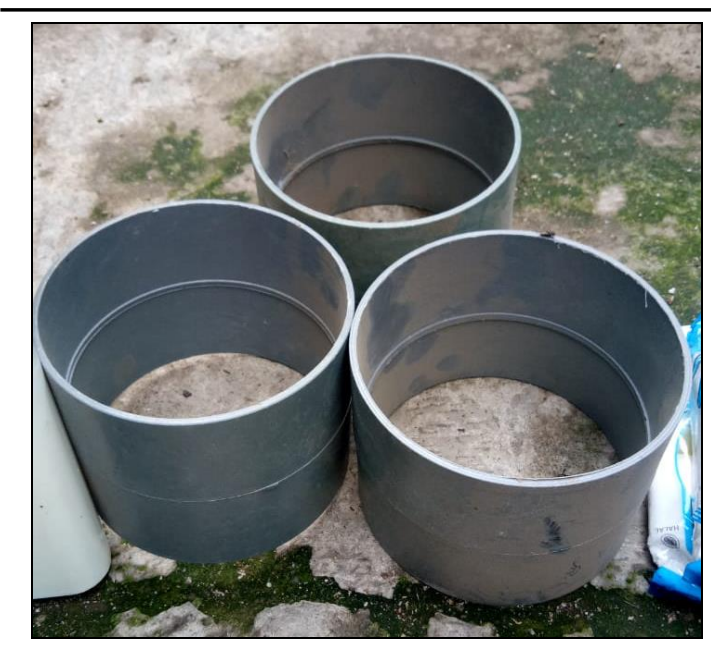

Gambar 3. Alat Pencetak UMB

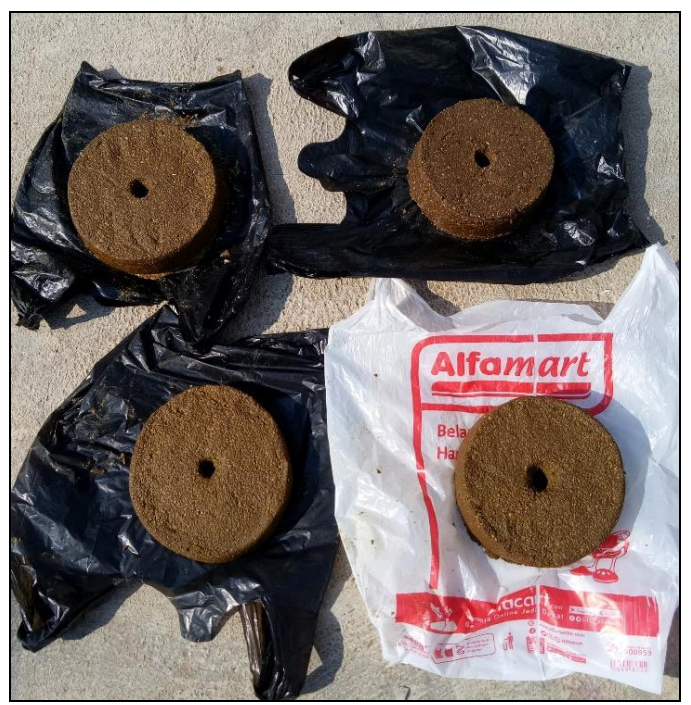

Gambar 4. UMB siap dikeringkan

\section{HASIL DAN PEMBAHASAN}

Proses pelaksanaan pembuatan Urea Molases Blok sebagai pakan bernutrisi tinggi untuk meningkatkan status reproduksi kambing PE dilakukan transfer teknologi tentang pentingnya pengetahuan mengenai penyakit repdoduksi dan manfaat urea molases blok.

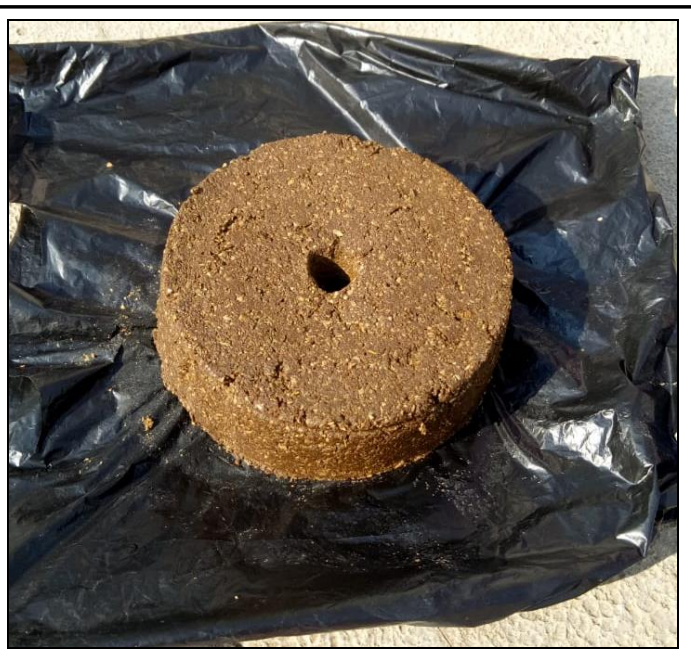

Gambar 5. Urea Molases Blok (UMB) yang sudah kering

Penerapan Langsung Pembuatan Urea Molases Blok (UMB) bersama anggota dan kelompok ternak As-Salam

Pembuatan UMB dilakukan oleh beberapa anggota kelompok ternak. Peternak sangat antusias dan bersemangat dalam mengikuti arahan proses pembuatan UMB. Kelompok ternak belum pernah melakukan pembuatan UMB, dan belum mengetahui kelebihan UMB dalam meningkatkan performans kambing.

\section{Pengaplikasian dan Evaluasi Penggunaan Urea Molases Blok (UMB)}

Urea Molases Blok (UMB) yang sudah jadi diberikan ke ternak selama 21 hari. Hasil yang didapat bahwa kambing sangat menyukai dan saling berebut untuk menjilati UMB yang digantung di pagar kandang. Satu UMB dapat digunakan untuk 3-4 ekor kambing. Kambing yang diberi UMB juga menunjukkan peningkatan nafsu makan lebih dari $60 \%$. Hal ini dikarenakan UMB mengandung nutrisi yang banyak seperti vitamin $\mathrm{A}, \mathrm{B}, \mathrm{D}$, protein, dan kalsium yang tinggi. Menurut pendapat Delima (2008), pemberian pakan tambahan pada ternak dapat meningkatkan produktivitas ternak secara signifikan. Hal ini didukung dengan pendapat Wasiati dan Faisal (2018) bahwa pemberian kalsium pada ternak perah dapat mempertahankan produksi susu. Molases yang 
Dwi Wijayanti, Firgian Ardigurnita

Perbaikan Reproduksi Kambing Perah di KTT As-Salam Melalui Pengembangan Urea Molases Blok (UMB)

digunakan dalam bahan pembuatan UMB yang bersifat manis meningkatkan nafsu makan kambing. Kalsium yang tinggi juga dapat memenuhi kebutuhan kambing PE. Ternak perah membutuhkan kalsium paling tinggi dibandingkan ternak lain hal ini karena ternak perah membutuhkan kalsium dalam memproduksi susu. Kambing yang mengalami kekurangan kalsium maka akan mengambil kalsium yang ada dalam tulang inilah salah satu yang menyebabkan kambing sering mengalami gangguan tulang atau oesteophorosis.

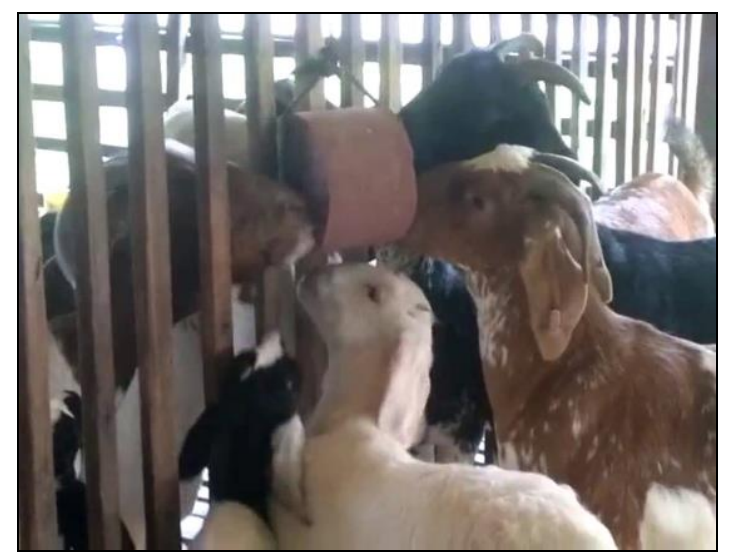

Gambar 6. Urea Molases Blok (UMB) diberikan kepada Kambing PE

\section{SIMPULAN}

Pelaksanaan pengabdian masyarakat ini berhasil dengan baik. Hal tersebut dibuktikan dengan antusiasme dari mitra dan anggota kelompok ternak As-Salam dalam mengikuti kegiatan ini cukup besar. Diperoleh pemahaman dan keberhasilan pembuatan Urea Molases Blok (UMB) dalam meningkatkan performans reproduksi kambing PE. Selain itu juga dengan pemberian UMB, terjadi peningkatan nafsu makan pada kambing PE.

\section{DAFTAR PUSTAKA}

Delima, M. (2008). Pengaruh pemberian urea molease mineral blok terhadap kadar mineral serum sapi yang memperlihatkan gejala defisiensi mineral. Jurnal Agripet, 8(1):45-49.

Murni, Rasmi \& Yatno, N. (2015). Pelatihan Pembuatan Lamtoro Mineral blok Pada peternakan desa pematang gajah Kabupaten muaro Jambi. Jurnal Pengapdian pada Masyarakat, 30:1-6.

Octavia, A., Masriani, I., Rosita, S, Pengajar, S., Ekonomi, F.\& Jambi, U. (2015). Jurnal Pengabdian pada Masyarakat, 30:40-9.

Setiarto, R. H.B. (2017). Prospek Dan Potensi Pemanfaatan Lignoselulosa Jerami Padi Menjadi Kompos, Silase Dan Biogas Melalui Fermentasi Mikroba. $J$ Selulosa, 3(02):51-66.

Sucipta, I. G. M. A., Siti, N.W., Partama, I. B. G., Cakra, I. G. L.O.i \& Mudita, I. M. (2016). Suplementasi Urea Molasis Blok untuk Meningkatkan Penampilan Kambing Peranakan Etawah yang Diberi Pakan Hijauan Gamal. J Agripet, 12(2):49.

Wasiati, H. \& Edi F. (2018). Peternakan kambing Peranakan Etawa di kabupaten Bantul. Jurnal Abdimas Unmmer Malang, 3(1): 8-14 